\title{
Media Literacy in Preventing the Spread of Radicalism in the Millennial Generation
}

\author{
F M Gasa*, A Wasita, B Hartanto, A B Gunawan and J A Citra \\ Communication Science Department, Faculty of Economics \& Communication, Bina Nusantara University, Jakarta, \\ Indonesia 11480 \\ *Corresponding Author Email: Frederik.gasa@binus.edu
}

\begin{abstract}
This study aims to deepen the understanding of the millennial generation in Malang on the importance of media literacy skills in preventing the spread of radicalism through social media. The units of analysis in this study were students from Brawijaya University and Muhammadiyah Malang University who were active in campus organizational activities. Researchers use a qualitative approach with an interpretive paradigm in order that researchers can obtain a more detailed perspective or point of view of the informant. The results showed that the millennial generation already understands the concept of media literacy and practices it in using social media so that radicalism spread through social media cannot influence them.
\end{abstract}

Keywords: Media Literacy, Radicalism, Millenial Generation

\section{INTRODUCTION}

In 2019, the National Intelligence Agency stated that the $17-24$ year age group was the most vulnerable to radicalism. This group is vulnerable for several reasons, one of which is the weak critical thinking ability [1].

This issue, where millennial groups are easily exposed to radicalism, is a common concern because the massive spread of radicalism is currently being carried out through social media - the media used by millennial to communicate, seek information, and channel expressions. Social media and online networking are very strategic choices for radical groups because messages disseminated are more difficult to detect, have broad potential impacts and are low cost [2].

The infiltration of radicalism into millennial groups will clearly become a serious concern from the government, especially because the learning environment, especially campuses, becomes a new locus of radicalism. Data from the Setara Institute states that there are 10 state universities (PTN) in Indonesia exposed to radicalism, namely University of Indonesia (UI), Syarief Hidayatullah State Islamic University (UIN), Bandung Institute of Technology (ITB), UIN Sunan Gunung Djati Bandung, Bogor Agricultural Institute (IPB), Gadjah Mada University (UGM), Yogyakarta State University (UNY), Brawijaya University (Unibraw), Mataram University (Unram), and Airlangga University (Unair) [3].

In terms of its distribution, campuses in East Java are quite worrying. Bridjen Pol Hamli said that a campus in East Java had 70 percent of students exposed to radicalism [4]. Meanwhile, in Malang City, the Head of Malang City Police, AKBP Asfuri said that there were two state universities (PTN) namely Brawijaya University and Malang State University which identified many students who voiced radicalism. The idea of the students was to replace Pancasila and NKRI with Islamic caliphates [5].

\section{RADICALISM IN INDONESIA}

After the fall of Suharto's dictatorial regime, Indonesia is facing a new era, the era of democracy. democracy opens space for freedom for anyone to express their opinions and other freedoms, including in organizing. Many organizations or political parties have grown with various types of foundations. in addition, radical groups in the name of religion also grow side by side with other political organizations or parties. This radical group is what becomes worrying because of the various actions it has taken.

The end of the New Order led to the opening of the political sphere for a great variety of new political actors. Moderate Muslim intellectuals were active in the pro-democratic reform movements that took to the streets in 1997 and early 1998 and demanded Suharto's resignation. While playing a vital role in the immediate events leading to the downfall of Suharto, the "movement for a democratic Muslim politics in Indonesia" (Hefner 2005,274 ) was soon effectively marginalized by a rising conservative (and often militant) spectrum of 
Islamist actors, ranging from transnational terrorist networks like Jemaah Islamiyah (JI) and Islamist militias to legal Islamist political parties and civil society groups. The radical fringe of political Islam has displayed a heterogeneous array of organizational structures, goals, applied strategies, and relationships with the state [6].

Such reported cases of Islamic radicalism might send a significant message that religious radicalism is frequently followed by violent actions. There is a parallel connection between religious radicalism and violence as the radicalism appears in the form of social resistance in accordance to its own religious understanding. There are, at least, three general tendencies of the radicalism. First, radicalism is perceived as a response towards the existing conditions, including assumption, idea, value, and institution regarded as deviant. Second, radicalism is not restricted to the form of such resistance, but also accompanied by an attempt to change the existing order with another one supposed to be better. Third, radicalism is equipped with a strong belief in a certain ideology and program, which can result in emotional reaction and violence [7].

Various acts of terror masterminded by certain radical groups have made Indonesia one of the countries that has received the red-light title from the international community. Data from the Global Terrorism Database (2007) shows that there were 421 cases of acts of terrorism from 1970 - 2007, and 90 percent of these acts occurred during the end of Soeharto's office until he entered the democratic era [8].

According to Hasan (2015) Domestic radical groups are often vocal and frequently attract media attention, which helps them to circulate their message. Particularly after 1998, in the aftermath of the fall of President Suharto (who repressed violent radical groups but, for a long time, other Muslim groups as well), the uprooting of communities due to rural-to-urban migration, the global imagery of radicalism, and the widening gap between the rich and poor are fuelling the recruitment of people for terrorist groups. Galamas (2015) said that regarding international groups, the number of Indonesians who have joined ISIS is highly contested. Although government reports in 2015 indicated 159 recruits, other reports state that 'this number can be much higher, making this country the biggest ISIS fighters' supplier in Southeast Asia' [9].

Social media, with their participatory qualities and potentially large reach, form a significant and promising site for the construction of counternarratives. Indonesia offers an excellent case study for examining (online) counternarratives for two reasons. First, as a Muslim-majority country, Indonesia is part of intra-Muslim debates about interpretations of Islam and countering radical Islam. Second, Indonesian counternarratives make up a useful case study because they are not specifically aimed at 'radicals' but, rather, at the larger moderate Muslim audience [9].

\section{SOCIAL MEDIA}

Social media is the media used for socializing [10]. Safko further stated that this simple definition is formed from two different concepts, namely social and media. Social refers to human's instinctive need to connect with other humans. Meanwhile, the media is an intermediary that is used to create relationships between humans. He concluded that the terminology of social media is defined as a set of technologies that can effectively connect fellow humans, build relationships, and trust.

Social media is also defined as the media used to develop social interaction, collaboration, sharing and participation [11]. Kaplan \& Haenlein (2011) said that social media can be roughly referred to as a "group of Internet-based applications that build on the ideological and technological foundations of the Web 2.0 and that allow the creation and exchange of user-generated content" [12].

The quick rise of social media platforms in the first decade of this century was part of a more general networked culture where information and communication got increasingly defined by the affordances of web technologies such as browsers and search engines. Social networking sites like Facebook, Twitter, and LinkedIn as well as usergenerated content sites, including YouTube and Flickr, became the core of a host of web-based applications that together formed an expansive ecosystem of connective media [13].

There are two distinct challenges associated with the conceptualization of social media. first, the speed at which the technology is expanding and evolving, challenges our ability to define clear-cut boundaries around the concept. Social media technologies include a wide range of PC and mobile-based platforms that continue to be developed, launched, relaunched, abandoned and ignored every day in countries throughout the world and at varying levels of public awareness. Secondly, social media services facilitate various forms of communication that are similar to those enabled by other technologies [14]. Social media cover a broad variety of scopes with specific functions and applications that can differ greatly between the different types of social media. 
The functions of social media are socializing with friends and family, romance and flirting, interacting with companies and brands, job seeking and professional networking, and doing business [15].

Social media has become so powerful because it has a wide reach and affects audiences. In this regard, radical groups use social media as a medium to disseminate radical ideas to the public, including students. In fact, the State Intelligence Agency (BIN), recently warned the public to be alert to varied ways used by radical groups in several educational institutions. BIN said that radicalism spread through (1) formal education lessons in radical Islamic boarding schools (2) the utilization of radical organizations network (3) education at the religion -focused university (4) the public sermons (5) books distributed free of charge (6) electronic media, such as television, radio, website and so forth. (7) and social media owned by a particular organization. Actually, there were researches by Greg Fealy and Anthony Bubalo in 2001, before the warn by the BIN, that suggest that there are three main channels for the spread of radical movements in Indonesia; social movements, Islamic educational institutions and the publication of ideas through electronic, printed and social media [16].

\section{MEDIA LITERACY}

The dissemination of radicalism through social media can be suppressed, one of which is by strengthening media literacy. Media literacy encourages us to adapt to developments in communication technology and opens our horizons to messages that are spread through new media.

Media literacy is formed from 3 building blocks, namely skills, knowledge, and personal locus. Skills are tools used to build knowledge, and it is this knowledge structure that organizes what has been learned and is directed by personal locus [17]. Media literacy is most commonly described as a skill set that promotes critical engagement with messages produced by the media. At its most basic, media literacy is the "active inquiry and critical thinking about the messages we receive and create," (Hobbs \& Jensen, 2009), and most proponents emphasize this connection to critical thinking. The U.S. National Association for Media Literacy Education (NAMLE) defines media literacy as "the ability to access, analyze, evaluate, create, and act using all forms of communication." What is notable about these definitions, and what we will see often forms the basis of media literacy curricula, is a focus on the interpretive responsibilities of the individual [18].
Kirwan, et al (2003) mention several reasons for the importance of media education or media literacy. The reasons for organizing media education or media literacy are: (1) We need to get enough information about the media, and why and how information is communicated. Humans need have the ability to assess information that can be trusted, (2) Mass media is an important part of the experience of many people, so we need to study mass media in addition to other forms of information and entertainment such as books, (3) It is important to provide learning on the experiences of children consuming media, and (4) Mass media is the main source of information, becomes part of our culture, and learners should understand how mass media shape meaning [19].

Media literacy is one of the skills or abilities that must be possessed in the digital era like today. The community, especially millennial groups, use social media every day and will certainly be exposed to various types of content which, if not anticipated, can have a negative impact on them. One form of content that has received attention from the government is content related to radicalism which is deliberately disseminated by radical groups through the internet and social media.

\section{RESEARCH METHODOLOGY}

This research used a qualitative approach with an interpretive paradigm. Taking account from various scholars, it is theoretically understood that interpretive paradigm allows researchers to view the world through the perceptions and experiences of the participants. In seeking the answers for research, the investigator who follows interpretive paradigm uses those experiences to construct and interpret his understanding from gathered data. Specifically, interpretivism supported scholars in terms of exploring their world by interpreting the understanding of individuals [20].

Researcher used case study methods. As a research strategy case studies are used in a variety of contexts and disciplines, for example, in organizations in marketing and information systems (IS); in small communities, households, families in psychology and social work; or in countries, nations or regions in political science (Davies, 2007; Mouton, 2001) in [21].

This study aims to explore the experience of the students that studying at Brawijaya University and Muhammadiyah Malang University with purpose to know how literate the students are in utilizing social media, especially in relation to how they deal with various issues of radicalism in the campus 
environment. Data was collected through focus group discussions and in-depth interviews. The FGDs and interviews were conducted online through zoom meetings, considering that this research was conducted during the Covid-19 pandemic.

The informants in the research are students who are actively involved and occupy important positions in the campus organization. The following is the profile of students who are the subject of this research.

TABLE 1. Informant profile

\begin{tabular}{|c|c|c|c|}
\hline Name & Institution & $\begin{array}{c}\text { Campus } \\
\text { Organizati } \\
\text { on }\end{array}$ & $\begin{array}{c}\text { Position in } \\
\text { Campus } \\
\text { Organizatio } \\
n \\
\end{array}$ \\
\hline $\begin{array}{l}\text { Adithya } \\
\text { K. } \\
\text { Wicakso } \\
\text { no }\end{array}$ & $\begin{array}{l}\text { Brawijaya } \\
\text { University }\end{array}$ & $\begin{array}{l}\text { Student } \\
\text { Executive } \\
\text { Board }\end{array}$ & $\begin{array}{l}\text { Director } \\
\text { General of } \\
\text { Community } \\
\text { Empowerm } \\
\text { ent }\end{array}$ \\
\hline $\begin{array}{l}\text { Dhenny } \\
\text { Z.S. Ravi }\end{array}$ & $\begin{array}{l}\text { Brawijaya } \\
\text { University }\end{array}$ & $\begin{array}{l}\text { Student } \\
\text { Executive } \\
\text { Board } \\
\end{array}$ & $\begin{array}{l}\text { Minister of } \\
\text { Human } \\
\text { Resources }\end{array}$ \\
\hline $\begin{array}{l}\text { Andi } \\
\text { Muhamm } \\
\text { ad }\end{array}$ & $\begin{array}{l}\text { Brawijaya } \\
\text { University }\end{array}$ & $\begin{array}{l}\text { Student } \\
\text { Executive } \\
\text { Board } \\
\text { Faculty of } \\
\text { Social and } \\
\text { Politics }\end{array}$ & $\begin{array}{l}\text { Deputy } \\
\text { Minister of } \\
\text { Public } \\
\text { Policy }\end{array}$ \\
\hline $\begin{array}{l}\text { Gilang } \\
\text { Drajat } \\
\text { Maulana }\end{array}$ & $\begin{array}{l}\text { Brawijaya } \\
\text { University }\end{array}$ & $\begin{array}{l}\text { Student } \\
\text { Executive } \\
\text { Board }\end{array}$ & $\begin{array}{l}\text { Vice } \\
\text { Chairman }\end{array}$ \\
\hline $\begin{array}{l}\text { Fathum } \\
\text { Mubin }\end{array}$ & $\begin{array}{l}\text { Muhammadi } \\
\text { yah Malang } \\
\text { University }\end{array}$ & $\begin{array}{l}\text { Governme } \\
\text { nt Science } \\
\text { Student } \\
\text { Associatio } \\
\mathrm{n}\end{array}$ & Chairman \\
\hline $\begin{array}{l}\text { Farah Tri } \\
\text { Vania }\end{array}$ & $\begin{array}{l}\text { Muhammadi } \\
\text { yah Malang } \\
\text { University }\end{array}$ & $\begin{array}{l}\text { Photograp } \\
\text { hy } \\
\text { Journalisti } \\
\mathrm{c} \\
\text { Associatio } \\
\mathrm{n}\end{array}$ & Chairman \\
\hline
\end{tabular}

\section{RESULT AND DISCUSSION}

Radicalism and The Role of Campus Organization Brigadier General Hamli's statement that 70 percent of students in one of the campuses in East Java are exposed to radicalism should be a serious concern not only of the Government, but all groups including the students themselves. It is feared that the campus environment will no longer be a place to gain knowledge but a nursery for the seeds of radicalist groups. The campus actually has to take serious steps starting from admission selection until finally students graduate.
University is a place where thoughts and ideas are discussed and even debated. Inside there is an academic group consisting of lecturers and students who, based on knowledge, always want progressive and positive change for the nation and state. Because the universities are very open to ideas and groups from certain schools, they are vulnerable to radical ideas and groups.

The Islamic activities in most campuses are actually monolithic, tend to be homogeneous, and do not accommodate the activities of other groups of fellow Muslims. This can be seen from the dominance of certain Islamic activities that are accommodated by the structural student organizations. Radical groups on several campuses use Islamic organizations as a front to spread their understanding and teachings [3].

There are various ways taken by radical groups in spreading radicalism in the campus environment, including one of them is through sermons in mosques. Preachers take advantage of moments during worship to convey hate speech or implicitly invite people to support certain beliefs. This often occurs during general election contestations because the preachers give a very tendentious sermon to prohibit their followers from choosing certain candidates who are considered not in accordance with Islamic teachings and are labeled kafir.

That similar thing has happened in Brawijaya University, to be precise during the 2019 presidential election contestation. One of the faculty mosques was once used as a place to convey hate speech and political views.

"So for example, from my personal experience, it actually happened in 2019. At that time I went to the faculty mosque at FISIP. Then there was one of the preachers, he delivered a hate speech but subtly, implicitly. He conveyed his views in the 2019 presidential election contest" (Farhan, 2020).

Another strategy used by radical groups is to use their cadres to recruit new members. This case has occurred where there was one student who indicated that he was affiliated with a radical group who tried to influence his friend to join the organization.

"In the past, there were some of my friends who could be said to have followed that sect or indicated that they were following this (radical) flow, as evidenced by the frequent cadres with friends from the department. Alhamdulilah now from three semesters invite him, embrace him, and educate him 
and alhamdulilah he is now practically independent of these things" (Dhenny, 2020).

Radical ideas and groups that develop on campus can be overcome in various ways, one of which is through empowering campus organizations driven by students. The campus organization, besides being a forum for students to apply the knowledge gained in the classroom, is also a "fortress" from the threat of radicalism in the campus environment.

Students work together with department and faculty managers to hold various activities aimed at counteracting the spread of radicalism. The first activity carried out was to provide material on state defense when new students took part in orientation activities.

"One method that is often used is to understand the state defense material during the orientation period, according to the guidelines from the Ministry of Education and Culture. In addition, conducting internal discussions on this material is an intellectual rejuvenation of fallacy ideas like this" (Dhenny, 2020).

Other activities carried out are through seminars and critical discussions about the values of Pancasila and the dangers of radicalism.

"The important role of OK (campus organization) in this case is how $O K$ can instill the Pancasila ideology in accordance with the Unitary Republic of Indonesia in every activity and also as a source of information that educates all students. (OK) provides agitation, intelligence and propaganda on what problems are happening in this country, such as radicalism and also has discussions with academicians, especially lecturers, in assessing this. The output can be in the form of seminars or open discussions that all students can participate in" (Andi, 2020).

Furthermore, students, as a millennial group, also take advantage of existing social media to publish various positive content aimed at fighting this radicalism.

"For me and the association (student association / HMJ) are working with lecturers in the department to create creative content on our social media either via Instagram, Line or YouTube. Sometimes we also make guest lectures or seminars with sources according to the topic, be it the topic of radicalism" (Fathum, 2020)

\begin{abstract}
"OK (campus organization) plays a very important role in this matter, because so far the official media which is attractive and effective is mostly accessed through $O K$. Through intelligence through social media and the existence of supporting programs, $O K$ can be an effective medium to anticipate the spread of negative or radical understandings" (Gilang, 2020)
\end{abstract}

\section{Media Literacy and Social Media Practices}

Millennials, including students, use social media for various needs. Social media is seen as a source of information that is easily accessible from anywhere using a smartphone. Students access information through various social media, such as Twitter, Line, and Instagram. One of the informants, namely Fathum, even used his social media to get the most up-to-date information about events that occurred in his area.

Social media is also a medium of communication and friendship. As a social media literate generation, students use social media to be able to maintain communication and friendship with their colleagues and parents. Then in social media practice, do these students understand media literacy?

For this millennial group, media literacy is not a strange concept. As the younger generation, students are well aware that they must have good media literacy skills, especially because they are exposed to information and news from the media every day, especially social media.

Conceptually, media literacy is interpreted in various ways by students. Media literacy is defined as a way to validate or understand and interpret messages and information obtained from various media, both print and social media (Fathum, Gilang, Dhenny, Andi, 2020). Media literacy is also seen as a guide or educational activity for the public to better understand how we access and analyze information so that it is useful for daily needs (Farah, 2020).

Another view that emerges is that media literacy is a person's process of receiving, analyzing and disseminating information on social media or from other sources of information. It takes a selective and critical attitude in receiving this information (Kahfi, 2020).

Students not only understand conceptually, but also practice this media literacy in everyday life. In receiving information and news through social media, students always cross-check the truth of the information and news first.

"It is necessary to carry out further searches regarding the information obtained, both 
from the source, the content of the information and when the information was disseminated" (Kahfi, 2020)

"For me, the key is not knowing from just one source. It is better if I first look for other sources and know the validity of the information provider (media) itself is important because often news or information that is viral is published by media that is not even credible" (Andi, 2020)

Students are also often exposed to issues of radicalism through social media. This issue was able to be resisted by students because of their good media literacy skills.

"Usually I do research as well as filter when I get certain information so that I can conclude the truth. At that time there were accounts that spread radical views such as the jhad and the constitution of the caliphate" (Gilang, 2020)

"I personally have never helped spread the radicalism that I got. I am a typical person who doesn't trust people with fast and concerning news. How do I validate news about radicalism? Usually I always look for news with other channels or from other references. Sometimes I also ask my friends who understand this. Because I personally like to explore and dig news from various perspectives, then after I get it, it will come back to me how to validate it. The cost is I look at the history or the emergence of this radicalism" (Fathum, 2020)

This media literacy ability is considered not yet a habit of Indonesian society, especially millennial groups. These students consider that there are still many people who are easily consumed by information and news that are not necessarily true. That false information and news is easily spread because our society does not have good literacy skills.

\section{CONCLUSION}

Millennial groups, especially students in Malang City, although they are often exposed to news or information related to radicalism through social media, do not necessarily affect their attitudes. The students have fortified themselves with knowledge of media literacy, so that the cross-checking data culture becomes a good culture that is instilled in themselves and by the campus organization where they work.

The issue of radicalism in the campus environment is both a sensitive and important issue to discuss. The advancement of social media allowed them to grow and network very quickly. Hopefully this research will be the start for further research, especially in order to prevent the millennial generation, the nation's future candidates, are not easily exposed to radicalism.

\section{ACKNOWLEDGMENTS}

This work is supported by Research and Technology Transfer Office, Bina Nusantara University as a part of Penelitian Terapan Binus entitled Menangkal Radikalisme di Era Disrupsi Digital Melalui Penguatan Literasi Media with contract number: No.025/VR.RTT/IV/2020 and contract date: 6 April 2020. Researchers also would like to thank our fellow lecturers at Bina Nusantara University, Malang Campus for providing their times to discuss with us so we are able to complete this research. Special thanks are also addressed to fellow students who are willing to be informants in this research even though we are in a situation that is not ideal because of this Corona pandemic.

\section{REFERENCES}

[1] F. Wardah, "5038396 @ www.voaindonesia.com.” 2019, [Online]. Available:

https://www.voaindonesia.com/a/bin-usia17-24-tahun-rentan-terpaparradikalisme/5038396.html.

[2] A. Sulfikar, "Swa-radikalisasi Melalui Media Sosial di Indonesia," J. Jurnalisa, vol. 4, no. 1, pp. 76-90, 2019, doi: 10.24252/jurnalisa.v4i1.5622.

[3] M. T. Yani, H. Harmanto, and A. Ahmadi, "Construction of Islamic Lecturers on Radicalism and Its Prevention Efforts in University in East Java, Indonesia," Int. J. Multicult. Multireligious Underst., vol. 7, no. $7, \quad$ p. 93, 2020, doi: 10.18415/ijmmu.v7i7.1736.

[4] P. Ariefana, “Ada-Di-Kampus-Jawa-Timur70-Persen-Mahasiswanya-Terpapar-

Radikalisme@ Jatim.Suara.Com.”2019, [Online]. Available: https://jatim.suara.com/read/2019/07/26/06 1000/ada-di-kampus-jawa-timur-70-persenmahasiswanya-terpapar-radikalisme.

[5] Z. Arifin, "Paham-Radikal-MengintaiMahasiswa-Baru-Kampus-Di-Malang @ 
Www.Liputan6.Com.” 2018, [Online]. Available:

https://www.liputan6.com/regional/read/35 44251/paham-radikal-mengintaimahasiswa-baru-kampus-di-malang.

[6] F. Heiduk, "Between a rock and a hard place: Radical Islam in post-Suharto Indonesia," Int. J. Conf. Violence, vol. 6, no. 1 , pp. 26-40, 2012, doi: 10.4119/UNIBI/ijcv.191.

[7] A. Muzakki, "The roots, strategies, and popular perception of islamic radicalism in Indonesia," J. Indones. Islam, vol. 8, no. 1, pp. 1-22, 2014, doi: 10.15642/JIIS.2014.8.1.1-22.

[8] Setiyawan, "The Rise of Radicalism and Terrorism in Indonesia and Malaysia," $J$. Chem. Inf. Model., vol. 53, no. 9, pp. 16891699, 2013.

[9] L. Schmidt, "Cyberwarriors and Counterstars: Contesting Religious Radicalism and Violence on Indonesian Social Media," Asiascape Digit. Asia, vol. 5, no. $1-2, \quad$ pp. $32-67,2018$, doi: $10.1163 / 22142312-12340088$.

[10] L. Safko, "The Social Media Bible Tactics,Tools." 2012.

[11] C. Fuchs and M. Sandoval, Routledge Studies in Science, Technology and Society: Critique, Social Media and the Information Society, vol. 2013. 2013.

[12] J. van Dijck and T. Poell, "Understanding social media logic," Media Commun., vol. 1, no. 1, pp. 2-14, 2013, doi: 10.12924/mac2013.01010002.

[13] J. van Dijck, The Culture of Connectivity: A Critical istory of Social Media. New York: Oxford University Press, 2013.

[14] J. A. Obar and S. S. Wildman, "Social Media Definition and the Governance Challenge An Introduction to the Special Issue," SSRN Electron. J., 2018, doi: $10.2139 /$ ssrn. 2663153 .

[15] T. Aichner, M. Grünfelder, O. Maurer, and D. Jegeni, "Twenty-Five Years of Social Media: A Review of Social Media Applications and Definitions from 1994 to 2019," Cyberpsychology, Behav. Soc. Netw., vol. 00, no. 00, pp. 1-8, 2020, doi: 10.1089/cyber.2020.0134.

[16] H. S. Zainiyati, "Curriculum, islamic understanding and radical islamic movements in Indonesia," J. Indones. Islam, vol. 10, no. 2, pp. 285-307, 2016, doi:
10.15642/JIIS.2016.10.2.285-308.

[17] W. J. Potter, Media Literacy Eighth Edition. 2016.

[18] M. Bulger and P. Davison, "The Promises, Challenges, and Futures of Media Literacy," J. Media Lit. Educ., vol. 10, no. 1, pp. 1-21, 2018, doi: 10.23860/jmle-2018-10-1-1.

[19] G. T. L. Toruan and N. Ruslinawaty, "Educating Communities Through Media Literacy in Preventing the Spread of Radicalism Content on the Internet," vol. 439 , no. Ticash 2019 , pp. 210-213, 2020, doi: 10.2991/assehr.k.200515.035.

[20] M. A. A. Abdelsamie et al., "The Franchising Relationship Quality: It is important?," Procedia - Soc. Behav. Sci., vol. 1, no. 2, pp. 24-27, 2014.

[21] S. R. Ponelis, "Using interpretive qualitative case studies for exploratory research in doctoral studies: A case of information systems research in small and medium enterprises," Int. J. Dr. Stud., vol. 10, pp. 535-550, 2015, doi: 10.28945/2339. 